Integrated Marketing Communications (IMC) A Comparative study of Arabic and International Research Literature with a Special Focus on The Sultanate of Oman

\begin{tabular}{c}
\hline Iman Zahra \\
\hline Assistant Professor \\
Mass Communication Department \\
College of Arts and Social Sciences \\
Sultan Qaboos University \\
hajri@squ.edu.om
\end{tabular}




\title{
Integrated Marketing Communications (IMC) A Comparative study of Arabic and International Research Literature with a Special Focus on The Sultanate of Oman
}

\author{
Iman Zahra
}

\section{Abstract}

Due to the interdisciplinary complicated nature of the concept Integrated Marketing Communications (IMC) that has only emerged in the communication field three decades ago and has ever since witnessed dramatic developments in itself and the related fields, the current research paper aims at: shedding more light onto the nature of IMC and the sciences that the concept emerged from; undergoing meta-analysis on a total of 122 Arabic and foreign research papers to track IMC research trends worldwide and discussing the notable gap between IMC research in the Sultanate of Oman and its practice.

Findings indicated that IMC is an interdisciplinary relatively new concept combining communication and marketing, then evolved further to include branding as an independent discipline.

A quantitative and qualitative gap between Arabic and international research literature concerning IMC was noted, due to the limitations and difficulties of conducting such research in the Arab World.

IMC research in the Sultanate falls short, although serious attempts were made in the marketing and branding research fields. Practical wise, most companies working in Oman are practicing the concept without putting it into proper evaluation.

Keywords: Integrated Marketing Communications, Advertising, Public Relations, IMC effectiveness, marketing.

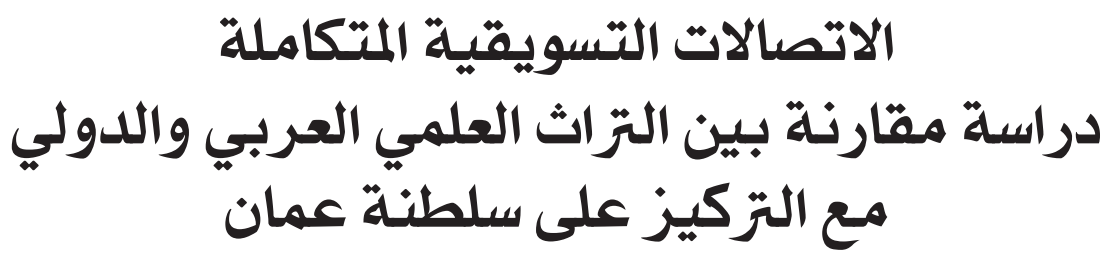

إيمان زهرة

يعتبر مفهوم الاتصالات التسويقية المتكاملة من المفاهيم البينية المعقدة التي بدأت المراجع الأجنبية في الاشارة الي ممارستها في بلداية

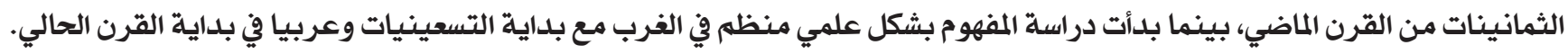

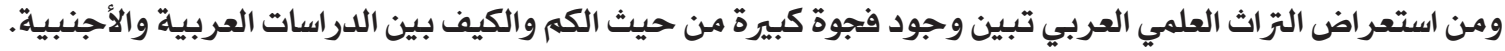

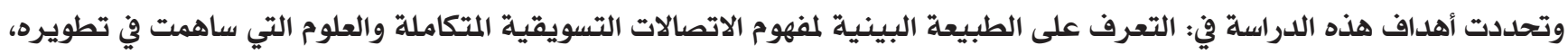

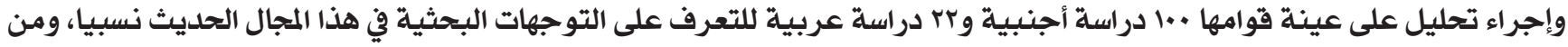

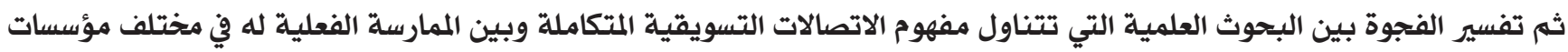

السلطنة.

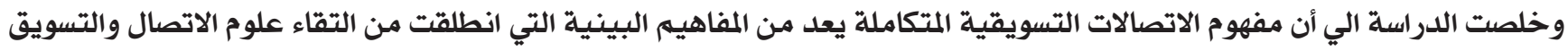

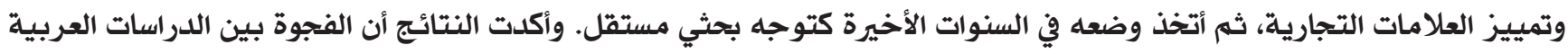

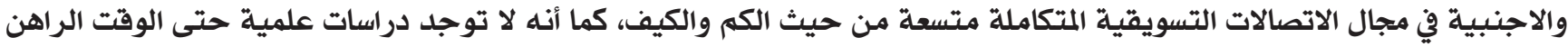

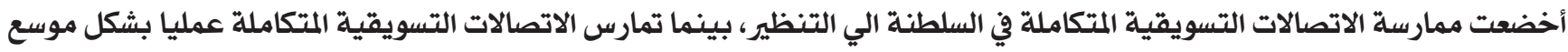
في مختلف مؤسسات السلطنة الحكومية والخاصة.

الكلمات المفتاحية: الاتصالات التسويقية المتكاملة، الإعلان، العلاقات العامة، التسويق، فعالية الاتصالات التسويقية المتكاملة. 


\section{Introduction}

The practice of IMC can trace its inception to the early 1980s when collegiate textbooks began to emphasize the concept of marketing communication. (EdmistonStrasser, 2007: 11). Coulson-Thomas in 1983 established himself as one of the first researchers to outline the broad spectrum of marketing communication channels. The first study on IMC was conducted by Caywood, Schultz, and Wang at the end of the 1980s, while the first "conceptual ideas" were published in the book "Integrated Marketing Communications" in the last decade of the past century (Schultz, Tannenbaum, and Lauterborn, 1993). Most likely nothing has gotten as much press activity and discussion meetings as has the concept IMC in the US in the year 1990 (Schultz, 1992).

As for the Arabic Literature, it did not fall far back from these dates, for the beginning of the third millennium had witnessed Arabic papers dwelling upon this

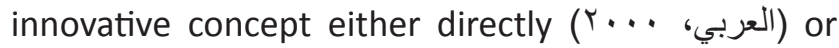
partially through utilizing certain components of the IMC concept especially IMC theory ( $Y$ … فريد، (ف) .

The objective of all marketing communications efforts is to present a coordinated, cohesive and unified branded message to a specific target audience (Sayre, 2008: 243).

Several factors have aided the creation of integrated marketing communications such as the Internet and social media, events, surprise or unexpected tactics, employee training and other approaches (Broussard, 2009: 11-12). Other factors included communication agency mergers and acquisitions, increasing sophistication of clients, increasing cost of traditional advertising media, bottom-line pressure, global competition, decreasing effectiveness of traditional media, decreasing cost of data-basing and media fragmentation (Hendrson, 1996; Hutton, 1996; Bruhn, 1997/1998; Griffin and Pasadeos, 1998; Eagle and Kitchen, 2000; Kliatchko, 2005). As a result, organizations started perceiving the competitive advantage and economic benefits of consistency and integration (Broussard, 2009: 11-12).

The American Association of Advertising Agencies definedIMCas: "aconcept of marketing communication planning which recognizes the added value of a comprehensive plan which evaluates the strategic roles of a variety of communication disciplines (e.g., general advertising, direct response, sales promotion, and public relations), and combines these disciplines to provide clarity, consistency, and maximum communication impact" (Hendrson, 1996:10). In short Integrated Marketing Communications or IMC is the management of all brand contact points through an integrated, audience-driven strategy. Message delivery through advertising, promotions, sponsorships, PR and Internet communications are vital to brand success (Sayre, 2008).

\section{Methodology}

\section{- Research Problem:}

Due to the interdisciplinary complicated nature of the concept Integrated Marketing Communications, that has only emerged in the communication field three decades ago and has ever since witnessed dramatic developments in itself and the fields it serve, research wise and practical wise, this paper sets out to explore the nature and aspects of integrated marketing communications in light of being an interdisciplinary developing concept emerging from a variety of social sciences; in addition to drawing a comparison between Omani, Arab and foreign IMC research literature to track the current research trends worldwide.

\section{- Research Objectives:}

The current research aims at achieving three major objectives:

1.Discussing the interdisciplinary nature of the IMC concept.

2.Specifying the main Arabic research topics in the IMC arena and how they can be compared to the foreign research literature.

3.Exploring the notable gap between IMC research in the Sultanate of Oman and the professional practice of the concept.

\section{- Research Questions:}

The current research is set to answer five major questions:

1.Why is Integrated Marketing Communications an interdisciplinary concept?

2.What are the main Arabic research topics in the IMC arena?

3.Are there points of comparison between Arabic and foreign IMC research literature and are they comparable in quantity and quality?

4.Where do the Omani research trends stand from IMC studies?

5.Is there a notable gap between research and practice considering IMC in the Sultanate of Oman?

- Research Method:

The current research resided to synthesize IMC 
empirical research in a meta-analytic framework. Meta-analysis in marketing research refers to "the analysis of a large collection of results from individual studies for the purpose of integrating the findings. Meta- analysis offers new opportunities for integrating and combining the contradictory outcomes of studies for analyzing variance in effect sizes across findings" (Laroche and Soulez, 2012: 79). Analyzing the sample in hand, the researcher attempted to synthesize the diverse findings of the various research papers into different IMC research trends and sub-trends to create a framework of common aspects tackled mostly in IMC studies. Furthermore, quantitative comparison of the accumulative count of IMC research papers in Arab and Foreign countries was implemented as well as the qualitative comparison concerning the different aspects and research trends presented in IMC literature.

\section{- Sampling Procedures}

The research utilized a purposive sample to implement the study because of the difficulty of assembling all the literature on IMC. The purposive sampling technique is simply defined as: "the deliberate choice of a participant due to the qualities the participant possesses" (Etikan et al., 2015: 2).

The following steps were followed to locate the study sample according to the criteria set in advance:

- Arabic research papers and dissertations were located through the Egyptian Universities Library consortium available at: www.eulc.edu.eg besides reviewing journals and publications of major Arab universities to locate studies related directly to IMC, mentioning IMC in the title of those research papers. To her best knowledge, the researcher located 22 Arabic research papers and dissertations originating from different universities and publications covering the time interval 1990-2015. Omani studies were located in the main library of Sultan Qaboos University. - The researcher resided to the following databases to locate the foreign IMC research literature published in English whether papers or dissertations (Ebsco Academic Research, Pro-Quest, Science Direct, Springer Link, Wiley Blackwell, and Sage Publications, in addition to Google scholar). The paper titles of the sample in hand must include directly the word IMC, thus locating 100 empirical studies that met the preset criteria covering the same time interval, although IMC studies are far more in quantity than this limited number.

\section{Results:}

In the upcoming lines the researcher will discuss the various aspects tackled in the paper then tend to answer the five research questions. Finally recommendations will follow to prove the researcher's viewpoint.

Integrated Marketing Communications as an interdisciplinary concept

To discuss this aspect thoroughly, a review of the origin and components of the IMC concept is presented hereafter:

Integrated Marketing Communications emerged as a promising field of study since the beginning of the nineties of the last century. The IMC concept draws its inspiration and has grown from the roots of the existing theories in the fields of Marketing and Mass Communication (McGrath, 2001).

The main foundation of the integrated marketing communication program is based primarily on the communication model, which consists of the sender, message, medium, receiver, feedback and noise. The sender represents the company or organization trying to convey a message to the consumer, which is represented as the receiver. The message is sent through different types of media, which interpret that message to the consumer. A good marketing communication plan occurs when the consumer can correctly interpret the initial messages as it was meant to be sent. (Benkahla, 2006).

Marketing is designed to build brand and customer relationships that generate sales and profits. The American Marketing Association (AMA) updated its definition of Marketing in 2007 as "the activity, set of institutions, and processes for creating, communicating, delivering and exchanging offerings that have value for customers, clients, partners, and society at large. It is a function within an organization, which focuses on managing customer relationships to benefit all of a brand's stakeholders (Moriarty et al., 2012: 62-63).

Historically the term IMC has emerged due to the confusion with the term sales promotion and the failure of promotion to be adopted by the advertising industry (Burnett, 2007: 206-207). The IMC terminology began to emerge in the eighties in the literature of Public Relations as well. A key milestone in IMC's emergence occurred in 1991, when a task force of academics and professionals was formed in an effort to agree on such fundamental issues as the most appropriate terminology and definition of the IMC concept (McGrath, 2001: 1). Companies first 
made a separate function out of the personal selling function, later out of advertising and still later out of public relations. The remaining tools were employed by the directors of these functional areas as needed.

The four major components that make up marketing communications are as follows (Burnett, 2007: 207208):

1- Advertising: any paid form of non-personal presentation of ideas, goods, or services by an identified sponsor. Most advertising messages are tailored to a group, and employ mass media such as radio, television, newspaper, and magazines.

2- Personal Selling: an oral presentation in a conversation with one or more prospective purchasers for the purpose of making sales.

3- Public Relations: a non-personal stimulation of demand for a product, service, or business unit by planting commercially significant news about it in a publish medium (i.e., publicity) or obtaining favorable presentation of it through vehicles not paid for by the sponsor.

It is concerned with the intentional, often persuasive communication where communicators and stakeholders are relationally active in creating, amending and re-constructing meanings (Daymon and Holloway, 2011: 4).

4- Sales Promotion: those marketing activities that add to the basic value of the product for a limited time period and thus directly stimulate consumer purchase and dealer effectiveness.

Marketing Communication includes all the identifiable efforts on the part of the seller that are intended to help persuade buyers to accept the seller's message and store it in retrievable form (Burnett, 2007: 207).

Other researchers think that components of the IMC mix can include any of the following besides the four major components (Balakrishnan, 1997):

- Direct Marketing and Telemarketing: it is defined as a multichannel system of marketing that uses a variety of media to connect to sellers and customers who deal with each other directly rather through an intermediary. The most important function of direct marketing is that it opens up the door for interactivity, and it is best known that the best practices of IMC engage stakeholders in meaningful and often interactive brand experiences. Interactivity - two way communication - is considered to be the heart of directing marketing ((Moriarty et al., 2012)

- Sales Force and distributor communication: They can be integrated with the relationship-marketing program to ensure that the sales staff concentrate on building relationships rather than short-term sales (Balakrishnan, 1997: 20).

- Corporate Identity and Communications: Corporate communication should be used to raise the awareness about the company and explain its activities. It refers to all that is not product-related communication (Balakrishnan, 1997: 19).

- Relationship Marketing: it is based on regular quality customer contact with information that reflects customer's needs (Balakrishnan, 1997: 20).

- Presentations, Exhibitions and Events: Like direct marketing and personal selling, exhibitions and presentations are considered a more personal and thus a "below the line" communication tool (DePelsmacker et al., 2010: 504). They are considered a part of a company's relationship marketing program with its customers and are a PR tool to support the corporate image of the company and the quality and fame of its brands (DePelsmacker et al., 2010: 509).

Instead of a functional approach, IMC attempts to integrate these functions into a collective strategy. If conducted properly, IMC results in a more effective achievement of an organization's communication objectives (Burnett, 2007: 206). IMC's objectives are not solely directed towards the achievement of sales growth or market share position, but maybe directed towards a number of different corporate, marketing or communication objectives or a mixture of all three (McCabe, 2009: 183).

The primary role of IMC is to systematically evaluate the communication needs and wants of the buyer and, based on that information, design a communication strategy that will:

1- Provide answer to primary questions of the target audience.

2- Facilitate the customer's ability to make correct decisions.

-3- Increase the probability that the choice they make most often will be the brand of the information provider (i.e., the sponsor or marketer). Marketers know that if they learn to fulfill this role, a lasting relationship with the customer can be established (Burnett, 2007: 205).

The basic objectives of marketing communications have been reduced to three more directives that are meaningful: 1 . To communicate 2 . To compete 3. To convince. The primary purpose of $M C$ is to communicate ideas to target audiences. Principles of effective communication are intended to achieve this task. Clearly, most of marketing is communications and it is in this context that communication is included 
as a purpose of MC (Burnett, 2007: 208).

While all communication includes the same basic components, marketing communication differs in two respects. First, the intent of $M C$ is to present a persuasive message, which reinforces the total offer made by the marketer. Second, marketing communication can be divided into two flows: internal and external, which are directed at different target audiences (Burnett, 2007: 212).

To make a long story short IMC is an integration approach because if there is a marketing opportunity, there must also be a communication opportunity.

Originally IMC was about creating "one voice, one look" all across the messages in a campaign. In recent years, it turned out that a more effective approach to IMC has moved from this narrow "execution" focus to a much broader focus on branding and customer brand perceptions. Companies now want to use everything that sends a message to create a coherent brand presence that leads to longer-term brand relationships (Moriarty et al., 2012).

Thus, IMC shifted from being an interdisciplinary approach combining communication and marketing to being an interdisciplinary approach combining communication, marketing and branding.

At the beginning of the 21st century, demands of IMC strategists have shifted from the emphasis on communication to the emphasis on the brand, thus another recent term: Integrated Brand Promotion (IBP) evolved and was defined as: "using the various communication tools coordinated to build and maintain brand awareness, identity and preference". Recent research and publications on IMC are now quickly recognizing the central role of the brand in communications (Semenik et. al., 2012). IMC is a common sense ongoing process for managing brand perceptions and experiences as well as customer expectations about the brand (Moriarty et al., 2012: 485). It is the voice of a brand. In general, the role of IMC is to inform, persuade and remind consumers of the brand essence, to engage them in a dialogue and to build relationships (DePelsmacker et al., 2010: 72). Everything that sends a brand message is a point of concern for brand communication. To be effective, these messages need to complement one another and present the same basic brand strategy (Moriarty et al., 2012:55). IMC can produce a stronger message consistency, help to build brand equity and create greater sales impact thus achieving clarity, consistency, and maximum impact through the seamless integration of discrete messages (Kotler et al., 2012:
482). The company wants to deliver a consistent and positive message with each contact. IMC leads to a total marketing communications strategy aimed at building strong customer relationships by showing how the brand can help customers solve their problems (Kotler et. al., 2012: 306).

Although almost everyone agrees that IMC is necessary for most brands' success, implementing these practices can be difficult. Complexity in measuring results, lack of recall and resistance to change pose the major challenges (Thorson and Duffy, 2012). IMC does not simply portray brands; it constitutes those brands in the sense that the meaning of the brand cannot be properly understood in separation from the consumer perceptions of its brand name, logo, advertising, media editorial, its portrayal in entertainment shows, peer comment and the communications associated with it (Hackley, 2010: 20).

The main Arabic research topics in the IMC arena In 2011 the researcher co-authored a paper discussing the Arabic literature tackling IMC (عبد الله وزهرة، 1) M $r-r \leqslant 9)$. Putting the previous references through thorough evaluation and collecting newly published Arabic researches, she traced 22 Arabic Research papers and dissertations only tackling major domains in IMC studies. Undergoing meta-analysis on the Arabic literature review, it seemed to be categorized under the following domains in which each study can tackle more than one domain:

1- Perceptions of the IMC concept and its practice by corporations and agencies:

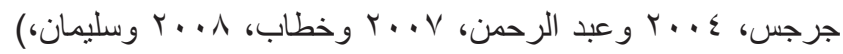

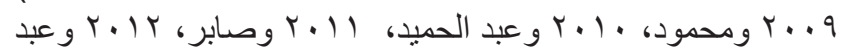

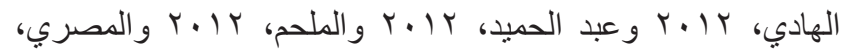
r Harb, 2013,) 2- The main principles of IMC practice:

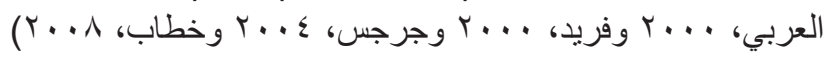

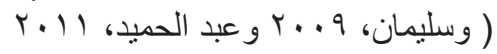

3- Managerial and organizational issues regarding IMC:

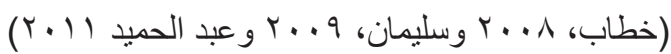

4- The IMC effects:

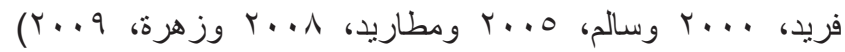

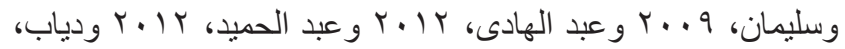

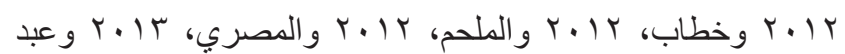

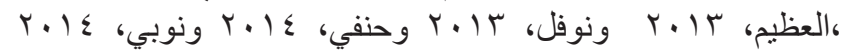
Harb, 2013).

General findings regarding the Arabic research literature categories are as follows: 
1- Perceptions of the IMC concept and its practice by corporations and agencies: Mostly, the previous Arabic researches have applied the survey approach. Data collection methods diversified between questionnaires, content analysis forms and in-depth interviews. Case studies and IMC models and theories were rarely utilized. Sampling frames also diversified between practitioners, executives, corporations, agencies, universities, non-profits ...etc.

Some findings in these studies contradicted other findings in other studies, which poses the need to conduct more research on this domain and its specific topics.

2- The main principles of IMC practice: Most researches in this domain were survey studies using questionnaires, interviews and content analysis forms. As the last domain IMC models and theories were rarely used and a fewer number came out with a conceptual model. Most researches neglected studying databases as a main principle of IMC execution.

3- Managerial and organizational issues regarding IMC: Most researches in this domain were survey studies executing questionnaires. Arabic researchers (as foreign ones as well) agreed on the constraints facing the practice of IMC in organizations most notably: the control of bureaucracy, inertia of administration, centralized decision-making and resistance to change in senior management and the practitioners themselves as well as the lack of financial resources.

4- The IMC effects: Most researches in this domain were survey studies using questionnaires and content analysis. Qualitative studies were rarely used. Models and theories were abundantly used here and conceptual models resulted from few researches.

The Arabic researches that studied branding via this domain would pave the way in front of many others to study branding variables and their relation to IMC. Studying non-profits was rare and was only traced to one Saudi case study in 2012. This trend should prevail into future studies due to the massive importance of non-profits in Arab communities.

Points of comparison between Arabic and foreign IMC research in terms of quantity and quality

The definition issues, perceptions, theoretical foundations, development and understanding of the IMC concept have been foremost among the concerns of scholars since IMC emergence as a formal field of study in the last decade of the past century. Vast array of pioneer IMC researchers considered these topics their sacred mission (Duncan and Everett, 1993; Nowak and Phelps, 1994; Grein and Gould, 1996; Phelps and Johnson, 1996; Brown, 1997; Schultz, 1997; Schultz and Kitchen, 1997; Schultz and Schultz, 1998; Hartley and Pickton, 1999).

In recent years, IMC studies have developed even further and tackled several current topics such as: the relationship between public relations and IMC, the management of IMC process by corporations and advertising agencies, the measurement of IMC outcomes and the effect of IMC process on brands.

Abdullah and Zahra (2011) have categorized the Arabic review of literature into four domains that the current study proved still existing. The English review of literature however, have been categorized by the same study (2011) into 10 domains, four of which are common with the Arabic literature. After thorough review the current study could trace the IMC English literature review to the same ten categories, thereby proving a notable quantity and quality gap between Arabic and international research.

First: The Common Domains shared between Arabic and International Literature Regarding IMC

1- Perceptions of the IMC concept and its practice by corporations and agencies: These studies traced the concept of IMC especially the earlier studies. Earlier and later studies covered practicing IMC in different corporations, services and agencies using different tools and techniques. This streamline of research started in the early nineties (Duncan and Everett, 1993); and continued steady until recently although being one of the oldest IMC domains. Recent studies included (Christensen et. al., 2005; Benkahla, 2006; Edmiston-Strasser, 2007; Horrigan, 2007; Gurau, 2008; Winter and Sanna, 2009; Pjero et. al., 2010; Garg, 2012; Murphy, 2012; Tsikirayi et al., 2013; King, 2013; MacArthur, 2014; Kerr and Patti, 2015; Seric et al., 2015; Kitchen, 2015; Lekhanya, 2015).

2- The main principles of IMC practice: These studies started tackling more sophisticated IMC domains, namely discussing planning, co-ordination and integration concepts within IMC. Interactivity and database usage were issues tackled in this domain as well. Old and new researches are abundant among this domain, starting in the mid-nineties (Carlson et. al., 1996) and continuing through the past decade (Orr and Cano-Lopez, 2005; Peltier et. al., 2006; Eagle et al. 2007; Gabrielli and Balboni, 2008; Caemmerer, 2009; Schultz, 2009; Dinnie et. al., 2010, Garg, 2012; MacArthur, 2014). 
3- Managerial and organizational issues: As IMC practice persisted in different corporations and agencies, scientific studies started tackling important issues regarding difficulties and factors impeding practicing the concept in the marketing field. The year 1993 marked the first known managerial IMC study (Duncan and Everett, 1993). Throughout the last decade organizational studies evolved (Ratnatunga and Ewing, 2005; Szanto and Harsanyi, 2007; Celebi, 2009; King, 2013; Ots and Nyilasy, 2015).

4- The IMC effects: This line of research is concerned with tracing the effects of IMC on different topics namely: the effects of IMC on branding and brand equity, effects of IMC on social marketing and utilizing IMC in the field of internal organization. Studies originated in this domain starting 1995 (Larson and Potter, 1995). Nevertheless, since 2005 till present IMC effects studies have diversified into totally new contexts (Madhavaram et. al., 2005; Ebren, 2006; Burgmann, 2007; Lovett, 2010; Erci, 2011; Dissanayake, 2012, Murphy, 2012; Tsikirayi et al., 2013; King, 2013; Luxton et. al., 2014; Dahl et al., 2015; Kuang-Jung et al., 2015; Lekhanya, 2015).

Second: The Unique International Literature Review These are the domains that were not discussed in any Arabic research according to the maximum knowledge of the researcher. These domains are as follows:

1- Measurement issues in IMC: These studies dwelt upon effectiveness of measurement issues in IMC being a recent field of study as it is. Starting the year 2000, this research domain will need further development in the upcoming years. (Katrandjiev,2000; Swain, 2004; Zavrsnik and Jerman, 2009; Nalca, 2009; Vantamay, 2011).

2- The IMC curricula in major universities: This topic deals with the issue of teaching IMC in different universities. Most of the studies in hand agreed that there resides a major gab between the theoretical teaching and the field practice of the concept (Kerr et al., 2004; Holm, 2006; Schultz et. al., 2007; Kerr et. al., 2008; Johnson, 2013) .

3- Theoretical foundations of the IMC approach: As shown before, studies and articles have been trying since the beginning to explore the IMC phenomenon, either through presenting conceptual definitions or conceptual frameworks to explain current IMC trends and futuristic perspectives. In the past decade, researchers covered similar issues in the hope of gaining more insight on the IMC context (Kliatchko, 2005; Grein and Gould, 2007; Kliatchko, 2008; and Grunig, 1998; Niemann et. al., 2003; Geoffrey, 2009; Hongcharu, 2010) and other non-major components as direct mail (Lariscy and Tinkham, 1996) and exhibits (Pitta et. al., 2006).

5- IMC versus Integrated communications (IC): In the beginning of the evolution of IMC, several concepts overlapped with it, one of which was integrated communications. Integrated communications is a term that referred to marketing dependence on databases. As time passed the two terms were used interchangeably (Andzela, 2001; Niemann, 2005; Geoffrey, 2009; Niemann and Grobler, 2011; Dissanayake, 2012).

6- Proposing specific IMC programs for certain entities: These studies dug deep into the visions, objectives and practices of certain corporations whether profit or non-profit or even celebrities. Such studies analyzed marketing factors and target audience then proposed an IMC effective program suitable only to be executed in the entity studied. These studies are mainly practical rather than depending on a theoretical base or theory (Garcia, 2008; Bailey, 2009; Cassat, 2010; Griewing, 2010). One Arabic research though (ملحم، 2012) conducted a case study on IMC in a non-profit in Saudi Arabia but rather he studied the status-quo instead of proposing an IMC plan for this entity.

Comparing Arabic and English literature on IMC, the current research confirmed the major findings of the past research conducted by Abdullah and Zahra (2011) as follows:

1- Withdrawal of the Arabic literature in comparison to the International literature in terms of quantity. Furthermore, the starting point for the Arabic literature was the beginning of this century versus the International literature in the late eighties of the past century.

2- Quantitative analysis prevailed in the Arabic literature versus International literature that resided to both qualitative and quantitative approaches.

3- Withdrawal of Arabic studies in terms of quality compared to international studies, as the last have tackled merely current topics in the field, especially dissertation-wise. This superiority may be the result of the longer period of time spent by international researchers in studying and developing all aspects of IMC, thus:

- Recently, studies have shifted from just analyzing the current situation in an IMC plan to developing specific IMC plans for corporations with certain budget limits and certain needs.

- Recently, studies have shifted from focusing merely 
on products to dealing with IMC programs of service organizations including universities and others.

- Recently, studies have been focusing on developing IMC plans for charities and non-profits; which is considered a major shift from just focusing on profit organizations.

- Depending on social networks as major components of IMC programs especially since being a cheap and available alternative for traditional media, to the extent that some studies built the whole campaign on social media in case of the unavailability of decent budgets which is mostly the situation in non-profits and charities.

- Recently, studies have shifted from focusing solely on mass media in IMC campaigns to giving credit to the means of interpersonal communication as well, such as: personal contacts, conversations, lectures and exhibitions that would play an equal and major role in these programs.

4- Despite the superiority of International literature on Arabic literature in addressing integrated marketing communications in all aspects due to differences in expertise, capabilities and freedom of scientific research, there are serious attempts in Arabic literature to launch their ideas beyond traditional frameworks and direct them to non-traditional arenas in the field of IMC especially recent studies.

\section{Omani Contribution to IMC studies}

As prior mentioned, Arabic literature regarding IMC is relatively weak in both quantity and quality. Omani research is no different for the researcher tried to locate any study that tackled this topic, but in vain. Omani Researchers though, have started since the nineties to tackle different marketing communications issues separately without tackling the comprehensive IMC discipline.

Al-Badaai as early as 1993 discussed undergoing marketing research in the Sultanate. Research is considered a major issue in the IMC process. Major components of IMC have been studied separately within the context of Marketing in Oman such as trade fairs (Al-Shamlan, 1998), online shopping (AlWahaiby, 2008) and even branding Oman as a tourism destination (Al-Darmaky, 2004) and brand equity of Omani heritage (Al-Balushi, 2010).

Establishing this strong base, Omani researchers should start tackling some of those major issues using IMC theories especially branding topics. The previous review of literature proved the eligibility of IMC approach to be applied in a variety of areas as: products, services, social marketing issues, profit and non-profit organizations, political marketing and political communication, therefore more studies should be directed towards these rich scopes to order to enrich the marketing and communication literature review in Oman.

The notable gap between research and practice considering IMC in the Sultanate of Oman

As mentioned before, IMC has not been submitted to proper research in the Sultanate. Nevertheless, field practice of IMC is notably more advanced than scholarly work. Most entities especially those producing consumer oriented products and services are presumed to be embracing the IMC approach whether planned or not.

Examples are massive: The ministry of Tourism states on its Arabic homepage that it is utilizing integrated marketing strategies to promote the Sultanate. The English homepage provides a list of tools used to execute their major strategy namely: campaigning, events, e marketing and promotions (website).

Ooredoo is a telecommunications company using almost every IMC tool to promote this service provider including: extensive advertising, publicity, promotions, events, philanthropy, sponsorship and social media (website).

Omantel the major provider of telecommunications service is using a similar IMC scheme as the latter executing: advertising, extensive publicity, promotions, events, philanthropy, sponsorship, social media and brand identity (website).

Other entities follow the same path as Oman Air, Bank Muscat and many others. I guess the reason behind practicing IMC but not naming it with its proper term is the same reason behind the obstacles facing IMC practice in all corporations in the world, i.e. measurement problems to determine the true effects of integration. As Dahlen stated: "Measuring the overall integrated marketing communications effort has to evaluate: sales, market share, customer perceptions and attitudes and customer satisfaction" (Dahlen et. al., 2010: 477).

The main methods of evaluating the individual components of the marketing communications mix amount to the sequential hierarchy of effects. These are translated into measurable metrics:

- Exposure to images and messages.

- Processing of the advertisement.

- Brand communication effects.

- Target audience action resulting from communications.

- Sales and market share 
- And brand equity (Dahlen et. al., 2010: 477)

Ditching the ultimate headache behind such complicated measurements and focusing only on sales and tangible results, most companies all around the world not only in Oman, reside to benefit from the term without submitting it to such complicated evaluations.

\section{Answering Research Questions:}

The previous review led to answering the research questions as follows:

Question (1): Why is Integrated Marketing Communications an interdisciplinary concept?

Literature suggests that IMC started out as being an interdisciplinary concept joining marketing and communications, and then developed into being a more complicated interdisciplinary approach combining three disciplines, namely communication, marketing and branding.

Question (2): What are the main Arabic research topics in the IMC arena?

Four main trends prevailed through the IMC Arabic research literature:

1- Perceptions of the IMC concept and its practice by corporations and agencies.

2- The main principles of IMC practice.

3- Managerial and organizational issues regarding IMC.

4- The IMC effects.

Question 3: Are there points of comparison between Arabic and foreign IMC research literature and are they comparable in quantity and quality?

The current study could trace the IMC English literature review to ten categories, thereby proving a notable quantity and quality gap between Arabic and international research and those are:

1- Perceptions of the IMC concept and its practice by corporations and agencies.

2- The main principles of IMC practice.

3- Managerial and organizational issues regarding IMC.

4- The IMC effects.

5- Measurement issues in IMC.

6- The IMC curricula in major universities.

7- Theoretical foundations of the IMC approach.

8- The relationship between IMC and components of the promotional mix.

9- IMC versus Integrated communications (IC).

10- Proposing specific IMC programs for certain entities.

Question 4: Where do the Omani research trends stand from IMC studies?

Arabic literature regarding IMC is relatively weak in both quantity and quality. Omani research is no different. Omani Researchers though, have started since the nineties to tackle different marketing communications issues separately without tackling the comprehensive IMC discipline.

Question 5: Is there a notable gap between research and practice considering IMC in the Sultanate of Oman?

IMC has not been submitted to proper research in the Sultanate. Nevertheless, field practice of IMC is notably more advanced than scholarly work. Most entities especially those producing consumer oriented products and services are presumed to be embracing the IMC approach whether planned or not.

Discussion and Recommendations

As proved, Integrated Marketing Communications is an interdisciplinary relatively new concept joining communication and marketing, then it evolved further to include branding as an independent discipline.

Arabic literature review consists to the maximum knowledge of the researcher of 22 studies during the period 1990-2015 evolving around 4 categories, while the international literature review consists of 100 researches evolving around 10 categories. This result is acceptable due to the diversity of international schools tackling IMC, versus the limitations and difficulties of conducting such research in the Arab World.

IMC research in the Sultanate falls short, although serious attempts are made in the marketing and branding research fields. Practical wise, most companies working in Oman are practicing the concept without putting it into proper evaluation. The market in Oman is open and thus IMC activities can thrive and results will be unlimited. In light of the previous discussion, IMC research and practice can thrive in the Arab world easily if certain recommendations will be executed:

- Encouraging Arab researchers to develop nontraditional measures to evaluate the effectiveness of integrated marketing communications. It is not clear whether any Arab attempts were made to develop indicators useful in evaluation. The effectiveness of IMC measurements should be studied more in Arabic literature in areas such as: irregular marketing response, competition, market heterogeneity and message content.

- Depending more on qualitative research rather than quantitative to analyze IMC further. Qualitative 
research gives more space for depicting theoretical gaps in the concept and thus helps to resolve them for more efficiency.

- Residing to more non-traditional IMC topics, through tackling IMC usage in: non-profits, political campaigns and NGOs.

- IMC curricula should be taught and researched thoroughly, in all Arab universities to clarify all aspects of the concept.

- Encouraging Omani corporations and entities to start practicing IMC extensively through training sessions digging into the depth of the concept.English

\section{References}

Arabic References:

جرجس، أماني، (ع.+r)، "صياغة خطة الاتصالات التسويقية السياحية الصصرية بالتطبيق على السوق السياحي الياباني"، رسالة ماجستير، كلية السياحة والفنادق، جامعة الإسكندرية.

حنفي، مروة، (عا+r)، "دور الاتصالات التسويقية في دعم أساليب التزويج السياسي للصر في الداخل: دراسة تطبيقية مقارنة علي

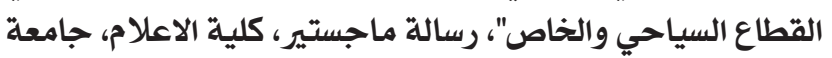

القاهرة. - اهر

الخريبى، إيناس، (11+r)، " الاتصالات التسويقية المتكاملة

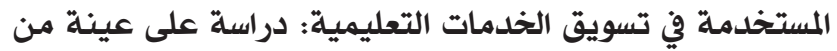

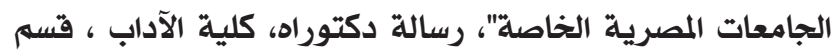
الإعلام ، جامعة حلوان.

خطاب، أحمد، (1+•r)، "إدراك الاتصالات التسويقية المتكاملة في مصر وأساليب ممارستها: دراسة تطبيقية على عينة من الشركات آدرات ووكالات الإعلان"، رسالة ماجستير، كلية الإعلام ، جامعة القاهرة.

خطاب، أحمد، (r/r)، "محددات الاتصالات التسويقية للهوية التجارية علي الأنساق الثقافية للجمهور المصري"، رسالة دكتوراه، كلية الاعلام، جامعة القاهرة.

دياب، أحمد، (rا+r)، "دور أساليب تنشيط المبيعات في السلوك الشرائي للمستهلك : دراسة في إطار الاتصالات التسويقية المتكاملة "، رسالة ماجستير، كلية الاعلام، جامعة القاهرة.

زهرة، إيمان، (9+9)، "تأثير الأنشطة الاتصالية المتكاملة على

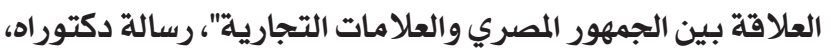
كلية الإعلام، جامعة القاهرة.

ساله، شيماء، (ب•+r)، "الاتصال التسويقي المتكامل في نشاط
السياحة الوافدة إلى مصر : دراسة تطبيقية على رعاية المناسبات والأحداث السياحية"، رسالة دكتوراه، كلية الآداب، قسى علوم

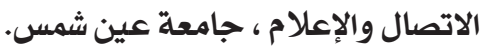

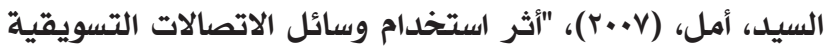

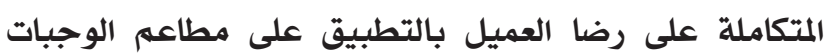

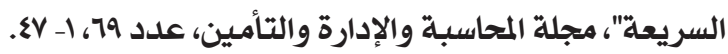

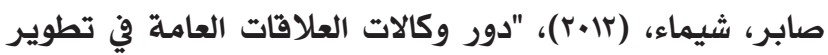
النشاط الاتصالي والتسويقي: دراسة مسحيه على وكالات العات العلاقات العامـة العاملة في مصر"، رسالة ماجستير، قسم الاعلام، كلية الآداب، جامعة جنوب الوادي.

عبد الحميد، سلوى، (9+4)، "الاتصال التسويقى المتكامل في الشركات متعددة الجنسية العاملة في مصر: دراسة تطبيقية"، رسالة دكتوراه، كلية الآداب، قسم علوم الاتصال والإعلام، جامعة ملية عين شمس.

عبد الحميد، طلعت، (rا+r)، "العلاقة بين الاتصالات التسويقية

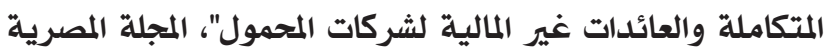

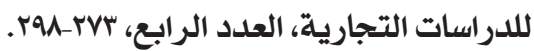

عبد العظيه، لبني، (rا.r)، "تأثير التكامل بين وظائف العلاقات العامة والتسويق علي الاتصالات التسويقية للمنظمة"، رسالة ماجستير، كلية الاعلام، جامعة القاهرة.

عبد اللّه داليا، وزهرة، إيمان، (11+r)، "بحوث الاتصالات التسويقية

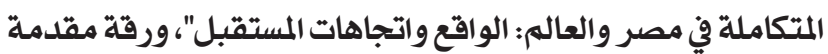
للمؤتمر الدولي السابع عشر لكلية الإعلام جامعة القاهرة ومنظمة

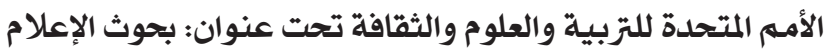

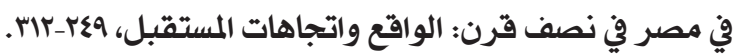

عبد اللّه سحر، (•r+r)، " استخدام الإنترنت كأداة لتفعيل الاتصالات

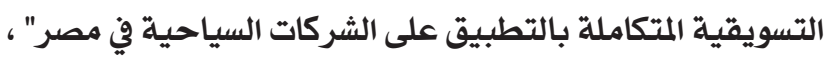
رسالة ماجستير، كلية التجارة، جامعة المنصورة.

عبد المنعم، أمل، (ז/+r)، "العلاقة بين الاتصالات التسويقية

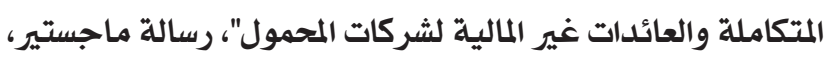
قسه إدارة الاعمال. كلية التجارة، جامعة المنصورة.

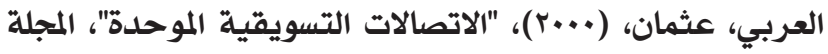

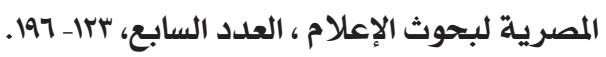

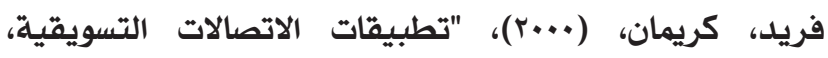

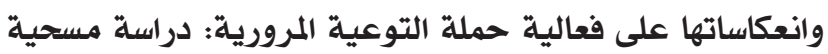

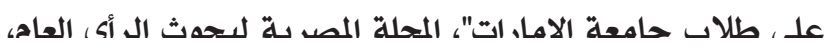


المصري، ابراهيه، (rا+r)، " دور الاتصالات التسويقية المتكاملة في تشكيل الصورة الذهنية لشركات الطيران العربية"، رسالة دكتور اهراه ، قسم الاعلام وعلوم الاتصال، كلية الآداب، جامعة عين شمس.

مطاريل، ناهد، (1+•r)، "تأثير الاتصالات التسويقية المتكاملة والتوجه بالماركة على قيمة الماركة"، مجلة المحاسبة والإدارة

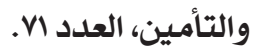

الللحه، صالح، (r/r)، "دور الاتصالات التسويقية المتكاملة في استقطاب المتطوعين وزيادة الموارد المالية للجمعيات الخيرية في

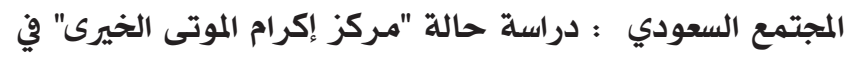

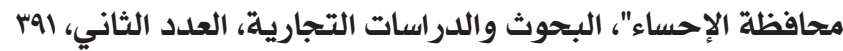
. TY -

نوبي، هاجر، (ع+r)، "دور الإتصالات التسويقية المتكاملة في

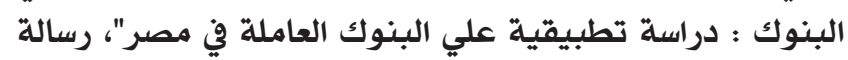
دكتور اه، قسم الاعلام، كلية الآداب، جامعة حلويله حلوان.

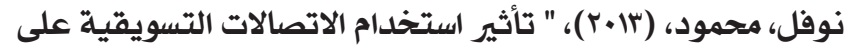
العلاقة بين البنوك و جمهورها: دراسة حالة"، رسالة ماجستير، كلية الاعلام، جامعة القاهرة.

\section{References}

Al-Badaai, S. N. (1993). A study of market research within the marketing environment of Oman. (Unpublished M.A. Thesis). University of Exeter.

Al-Balushi, M. K. (2010). Consumer-based heritage brand equity: conceptualization and measurement. (Unpublished PhD Dissertation). University of Manchester. England.

Al-Darmaky, S. J. (2004). Marketing Oman as an international tourist destination. (Unpublished M.A. Thesis). University of Hull. England.

Al-Shamlan, A. A. (1998). Trade fairs as a dynamic component of the marketing strategy. (Unpublished M.Sc. Thesis). University of Hull, England.

Al-Wahaiby, A. S. (2008). Barriers to adopting online shopping in the Sultanate of Oman. (Unpublished M.Sc. Thesis). University of Surrey, England.

Andžela Armonienè, A. (2001). Integrated Communication: A Phenomenon in a Nascent State.
Informing Science, June, 51- 57.

Bailey, K. (2009). Volunteer Center of Johnson CountyIntegrated Marketing Communications: Strategic Analysis and Recommendation. (Unpublished M.A. Thesis). William Allen White School of Journalism and Mass Communications. University of Kansas.

Balakrishnan, A. (1997). Integrated Marketing Communications. (Unpublished Diploma Paper). Mudra Institute of Communication.

Benkahla, S. M. (2006). A Study of the History and Use of Integrated Marketing Communications Within Publications from 1991-2005. (Unpublished M.A. Thesis). Journalism Department. Morgantown. West Virginia.

Broussard, S. L. (2009). Source -Message-Receiver In integrated marketing communication: A Study Of U.S. Institutional Advancement. (Unpublished PhD Dissertation). The Graduate School of The University of Southern Mississippi.

Brown, J. (1997). Impossible Dream or Inevitable Revolution? Investigating the Concept of Integrated Marketing Communications. Journal of Communication Management, 2(2), 70-81.

Bruhn, M. (1997/1998). Integrated Marketing Communications: a German Perspective. Journal of Integrated Communications, 1-6.

Burgmann, I. (2007). Integrated marketing communications: Implementation and application issues in consumer-focused companies. (Unpublished PhD Dissertation). University of Hull. United Kingdom. Burnett, J. J. (2007). Nonprofit Marketing: Best Practices. New Jersey: John Wiley and Sons Inc.

Caemmerer, B. (2009). The planning and implementation of integrated marketing communications. Marketing Intelligence \& Planning, 27(4), 524- 538.

Carlson, L. et. al. (1996). Does environmental advertising reflect integrated marketing communications? An empirical investigation. Journal of Business Research, 37, 225-232.

Cassat, J. (2010). An integrated marketing 
communications plan to build brand awareness for TLC for Children and Families: a not-for-profit organization helping children in crisis. (Unpublished M.A. Thesis). The University of Kansas.

Caywood, C. (2010). Integrated Marketing Communications. In. Kitchen, P. \& Burgmannm I. (Eds), Integrated Marketing Communication. Wiley International Encyclopedia of Marketing, John Wiley \& Sons Ltd.

Çelebi, S. (2009). Agency and Client Practitioners' Perceptions and Practices of IMC. Journal of Yasar University, 4(14), 2205-2236.

Christensen, L. T. et. al. (2005). Integrated Marketing Communication and Postmodernity: an odd couple?. An International Journal, 10(2), 156-167.

Dahl, S. et. al. (2015). Integrated marketing communications and social marketing: Together for the common good?. Journal of Social Marketing, 5(3), 226-240.

Dahlen, M. et. al. (2010). Marketing Communications: A Brand Narrative approach. West Sussex: Wiley.

Daymon, C. and Holloway, I. (2011). Qualitative Research Methods in Public Relations and Marketing Communications. 2nd ed. New York: Routledge.

De Pelsmacker, P. et. al. (2010) Marketing Communications: A European Perspective. 4th ed. Harlow: Pearson Education Limited.

Dinnie, K. et. al. (2010). Nation Branding and Integrated Marketing Communications: An ASEAN Perspective. International Marketing Review, 27(4), 388-403.

Dissanayake, D. (2012). Integrated Marketing Communications and corporate reputation: Evidences from Dell Computer Corporations. Researchers World , 3(3), 26-33.

Duncan, T. R. and Everett, S. E. (1993). Client Perceptions of Integrated Marketing Communications. Journal of Advertising Research, 33(3) 30-39.

Eagle, L. and Kitchen, P. J. (2000). IMC, brand communications, and corporate cultures: Client/
Advertising Agency co-ordination and cohesion: A two-nation qualitative comparison. European Journal of Marketing, 34(5/6), 667- 686.

Eagle, L. et. al. (2007). Insights into interpreting integrated marketing communications. European Journal of Marketing, 41(7/8), $956-970$.

Ebren, F. (2006). Impact of integrated marketing communication programs in enhancing manager and employee performance. A paper presented at International Conference on Human and Economic Resources, Izmir, 28-35.

Edmiston-Strasser, D. M. (2007). An examination of integrate marketing communication In U.S. public institutions of higher education. (Unpublished PhD Dissertation). Faculty of the Graduate School. Maryland University College.

Ercis, M. S. (2011). Importance of integrated marketing communication components regarding brand promotion and their effects on company performance: An Empirical Research. Research Journal of Economics, Business and ICT, 1, 13-21.

Etikan, I. et al. (2015). Comparison of Convenience Sampling and Purposive Sampling. American Journal of Theoretical and Applied Statistics, 5(1), 1-4.

Gabrielli, V. and Balboni, B. (2008). SME practice towards integrated marketing communications. Marketing Intelligence \& Planning, 28(3), 275-290.

Garcia, E. (2008). Hathmore Technologies integrated marketing communications: strategic analysis and recommendations. (Unpublished M.A. Thesis). William Allen White School of Journalism and Mass Communications. University of Kansas.

Garg, A. K. (2012). Integrated marketing communications: A case study of Nirma Group of Companies. International Journal of Management Research and Reviews , 2(12), 2098-2110.

Geoffrey, B. (2009). Integrating strategic relationship management: Evaluating public relations as relationship management in integrated communication. (Unpublished M.A. Thesis). University of Maryland, College Park. 
Grein, A. F. and Gould, S. J. (2007). Voluntary codes of ethical conduct: Group membership salience and globally integrated marketing communications perspectives. Journal of Macromarketing, 27(3), 289302.

Grein, A. F. and Gould, S. J. (1996). Globally integrated marketing communications. Journal of Marketing Communications, 2(3), 141-158.

Griewing, S. (2010). Integrated marketing communications plan for singer-songwriter Alexa James. (Unpublished M.A. Thesis). School of Journalism and Mass Communications. University of Kansas.

Griffin, G. W. and Pasadeos, Y. (1998). The Impact of IMC on Advertising and Public Relations Education. Journalism and Mass Communication Educator, 53 (2), 4-18.

Grunig, J. E. and Grunig, L. A. (1998). The relationship between public relations and marketing in excellent organizations: Evidence from the IABC study. Journal of Marketing Communications, 4 (3), 141-162.

Gurau, C. (2008). Integrated online marketing communication: Implementation and management. Journal of Communication Management, 12(2), 169184.

Hackley, C. (2010). Advertising and promotion: An integrated marketing communications approach. 2nd ed., California: Sage.

Harb, N. (2013). Using integrated marketing communications to improve the image of a destination after crisis: A case study from Egypt after the 25th مجلة اتحادات الجامعات العربية للسياحة والضيافة.January Revolution 115-125, (2)10,.

Hartley, R. and Pickton, D. (1999). Integrated marketing communications requires a new way of thinking. Journal of Marketing Communications, 5(2), 97-106.

Hendrson, A. W. (1996). Perceptions of industry leaders regarding the use of integrated marketing communication. (Unpublished M.A. Thesis). Faculty of Texas Tech University.

Hongcharu, B. (2010). A model of public relations processes for persuasion: Implications for integrated marketing communications in the internet era. Advances in Business-Related Scientific Research Journal (ABSRJ), 1(2), 145-155.

Horrigan, D. W. (2007). Integrated marketing communications in higher education. (Unpublished PhD Dissertation). University of Connecticut.

Hutton, J. G. (1996). Integrated marketing communications and the evolution of marketing thought. Journal of Business Research, 37(3), 155162.

Johnson, K. (2013). Facilitating cooperative learning in online and blended courses: An example from an integrated marketing communications course. American Journal of Business Education , 6(1), 33-40. Katrandjiev, H. I. (2000). Some aspects of measuring integrated marketing communications (IMC). Economics and Organization, 1(8), 87-93.

Kerr, G. F. et. al. (2008). An inside-out approach to integrated marketing communication: An international analysis. International Journal of Advertising, 27(4), 511-548.

Kerr, G. F. et. al. (2004). Integrated marketing communication: New discipline with an old learning approach (A Syllabi Analysis). Paper presented the Conference Proceedings of Australia and New Zealand Marketing Academy, Wellington, New Zealand.

Kerr, G. and Patti, C. (2015). Strategic IMC: From abstract concept to marketing management tool. Journal of Marketing Communications, 21(5), 317-339 King, A. L. (2013). Integratedmarketing communications (IMC) variables that influence perceived return on Investment (ROI) in higher education: Chief marketing officers' perceptions. (Unpublished PhD Dissertation). West Virginia University.

Kitchen, P. J. (2015). Integrated marketing communication: Making it work at a strategic level. The Journal of Business Strategy, 36 (4 ), 34-39.

Kliatchko, J. (2005). Towards a new definition of integrated marketing communications (IMC). International Journal of Advertising, 24(1), 7-33.

Kliatchko, J. (2008). Revisiting the IMC construct: 
A revised definition and four pillars. International Journal of Advertising, 27(1), 133-160.

Kotler, P. et. al. (2011). Principles of Marketing: Arab World Edition, Harlow: Pearson Education Limited.

Kotler, P. et. al. (2012). Marketing Management: Arab World Edition. Harlow: Pearson Education Limited.

Kuang-Jung, C. et. al. (2015). Integrated Marketing Communication, collaborative marketing and global brand building in Taiwan. International Journal of Organizational Innovation (Online) , 7(4) , 99-107.

Lariscy, R. A. W. and Tinkham, S. F. (1996). Use and impact of direct mail in the context of integrated marketing communications U.S. Congressional Campaigns in 1982 and 1990. Journal of Business Research, 37, 233-244.

Laroche, P. and Soulez, S. (2012). Meta-Analysis for Marketing Research. Recherché et Applications en Marketing (English Edition), 27(1), 79-104.

Larson, T. and Potter, J. (1995). Integrated marketing communication management: An applied hierarchy of effects model for evaluating Not- for- Profit organizations. Journal of Nonprofit and Public Sector Marketing, 3(2), 23-36.

Lekhanya, L. M. (2015). The role of integrated marketing communications in enhancement of SMEs growth in South Africa. Journal of Economics and Behavioral Studies, 7(2), 139-144.

Lovett, K. L. (2010). Integrated marketing communication and the promotion of iPhone applications. (Unpublished M.A. Thesis). Hawaii Pacific University.

Luxton, S. et. al. (2014). Integrated marketing communication capability and brand performance. Journal of Advertising, 44(1), 37-46.

MacArthur, E. (2014). More than a library: An outline for an integrated marketing communications campaign. (Unpublished M.A. Thesis). Rochester Institute of Technology.

Madhavaram, S. et. al. (2005). Integrated marketing communication (IMC) and brand identity as critical components of brand equity strategy. Journal of Advertising, 34(4), 69-80.

McCabe, S. (2009). Marketing communications in tourism and hospitality: concepts, strategies and cases. Oxford: Elsevier.

McCracken, J. C. (1997). Integrated marketing communications: The effect of advertising and retrieval cue congruency on memory for advertised target Information and preference for consumer packaged goods. (Unpublished PhD Dissertation). Department of Marketing of the College of Business Administration. University of Cincinnati.

McGrath, J. M. (2001). Integrated marketing communications: An empirical test of its effectiveness. (Unpublished PhD Dissertation).The Pennsylvania State University.

Mendez, C. (2009). Anthropology and ethnography: Contributions to integrated marketing communications. Marketing Intelligence \& Planning, 27(5), 633-648.

Micu, A. C. (2005). Testing for a synergistic effect between online publicity and advertising in an integrated marketing communications context. (Unpublished PhD Dissertation), The Faculty of the Graduate School of University of Missouri-Columbia. Moriarty, S. E. (1994). PR and IMC: The benefits of integration. Public Relations Quarterly, 39(3), 38-44. Moriarty, S. et. al. (2012). Advertising and IMC. 9th ed. Harlow: Pearson Education Limited.

Muñoz-Leiva, F. et. al. (2015). Discovering prominent themes in integrated marketing communication research from 1991 to 2012: A co-word analytic approach. International Journal of Advertising, 34(4), 678-701.

Murphy Gerber, D. C. (2012). Integrated marketing communication (IMC) and ethnic target marketing: A communitarian ethical framework in action". (Unpublished PhD Dissertation). Duquesne University. Nalca, C. K. (2009). Flexible models of integrated marketing communications effects. (Unpublished PhD Dissertation). Desautels Faculty of Management. McGill University. Montreal, QC, Canada.

Niemann,I.(2005).Strategicintegratedcommunication 
implementation: Towards a South African conceptual model. (Unpublished PhD Dissertation). University of Pretoria. South Africa.

Niemann, I. et. al. (2003). Integrated marketing communication (IMC) and the role of public relations (PR) therein: $A$ case study of University $X$. Communicare, 22(1),22- 59.

Niemann-Struweg, I. and Grobler, A. F. (2011). South African marketing and communication agencies' understanding of integrated communication (IC): A true reflection of the concept. PRism, 8(1), 1-13.

Nowak, G. J. and Phelps, J. (1994). Conceptualizing the integrated marketing communications' phenomenon: An examination of Its Impact on advertising practices and its implications for advertising research. Journal of Current Issues and Research in Advertising, 16(1), 49-66.

Orr, D. and Cano-Lopez, J. (2005). The role of data integration in integrated marketing communications planning. Journal of Direct, Data, and Digital Marketing Practice, 7(2), 137-145.

Ots, M. and Nyilasy, G. (2015). Integrated marketing communications (IMC): Why does It fail? An analysis of practitioner mental models exposes barriers of IMC implementation. Journal of Advertising Research, 55(2), 132-145.

Owen, A. R. (1996). Breaking through the clutter: The use of video news releases in integrated marketing communications. (Unpublished PhD Dissertation). The University of Florida.

Peltier, J. W. et. al. (2006). Interactive IMC: The relational-transactional continuum and the synergistic use of customer data. Journal of Advertising Research, 46(2), 146-159.

Phelps, J. and Johnson, E. (1996). Entering the quagmire: Examining the 'meaning' of integrated marketing communications. Journal of Marketing Communications, 2(3), 159-172.

Pitta, D. A. et. al. (2006). Integrating exhibit marketing into integrated marketing communications. Journal of Consumer Marketing, 23(3), 156-166.

Pjero, E. et. al. (2010). Integrated marketing communication and its measurement in Albania reality. International Review of Business Research Papers, 6(4), $77-89$.

Ratnatunga, J. and Ewing, M. T. (2005). The brand capability value of Integrated Marketing Communication (IMC). Journal of Advertising, 34(4), 25-40.

Sayre, S. (2008). Entertainment marketing and communication: Selling branded performance, people and places. New Jersey: Pearson Prentice Hall.

Schultz, D. E. ( 2009). Solving marketing problems with an integrated process. International Journal of Integrated Marketing communication, 1(1), 7-16.

Schultz, D. et. al. (2007). In search of a theory of integrated marketing communication. Journal of Advertising Education, 11(2), 1-27.

Schultz, D. E. and Kitchen, P. J. (1997). Integrated marketing communications in US advertising agencies: An exploratory study. Journal of Advertising Research, 37(5), 7-17.

Schultz, D. E. and Schultz, H. F. (1998). Transitioning marketing communication into the Twenty-First Century. Journal of Marketing Communications, 4(1), 9-26.

Schultz, D. E. (1992). Integrated marketing communications. Journal of Promotion Management, 1(1), 99-104.

Schultz, D. E. (1997). The evolving nature of integrated communications. Journal of Integrated Communications, (1997-1998 edition), 11-18.

Schultz, D. E. et. al. (1993). Integrated marketing communications. Lincolnwood, Chicago: NTC Publishing Group.

Selker, S. M. (2011). Enhancing publicityand promotion: Applying Gerard Hauser's theory of Reticulate Public Spheres to encourage discourse for integrated marketing communication (IMC). (Unpublished PhD Dissertation). McAnulty College and Graduate School of Liberal Arts. Duquesne University.

Semenik, R. J. et. al. (2012). Advertising and 
Promotions: An Integrated Brand Approach. 6th ed., Australia: South-Western Cengage Learning.

Seric, Maja. et. al. (2015). Insights on integrated marketing communications: Implementation and impact in hotel companies. International Journal of Contemporary Hospitality Management, 27(5) , 958979.

Swain, W. N. (2004). Perceptions of IMC after a decade of development: Who's at the wheel, and how can we measure success?. Journal Of Advertising Research, 44(1), 46-65.

Szanto, S. and Harsanyi, D. (2007). Integrated marketing communication In higher education?. EU Working Papers, 2, 47-58.

Thorson, E. and Duffy, M. (2012). Advertising age: The principles of advertising and marketing communication at Work. Australia: South-Western Cengage Learning.

Tsikirayi, C. et. al. (2013). Impact of integrated marketing communications mix (IMCM) in small to medium enterprises (SMEs) in Zimbabwe as a marketing tool. Research in Business and Economics Journal, 7, 1-12.

Vantamay, S. (2011). Performances and measurement of integrated marketing communications (IMC) of advertisers in Thailand. Journal of Global Management, 1(1), 1-12.

Zavrsnik, B. and Jerman, D. (2009). Conceptualization and Measurement of Integrated Marketing Communication. Proceedings of 7 th International Conference «Economic Integration, Competition and Cooperation", Opatija, University of Rijeka, Faculty of Economics, 1-12. 
